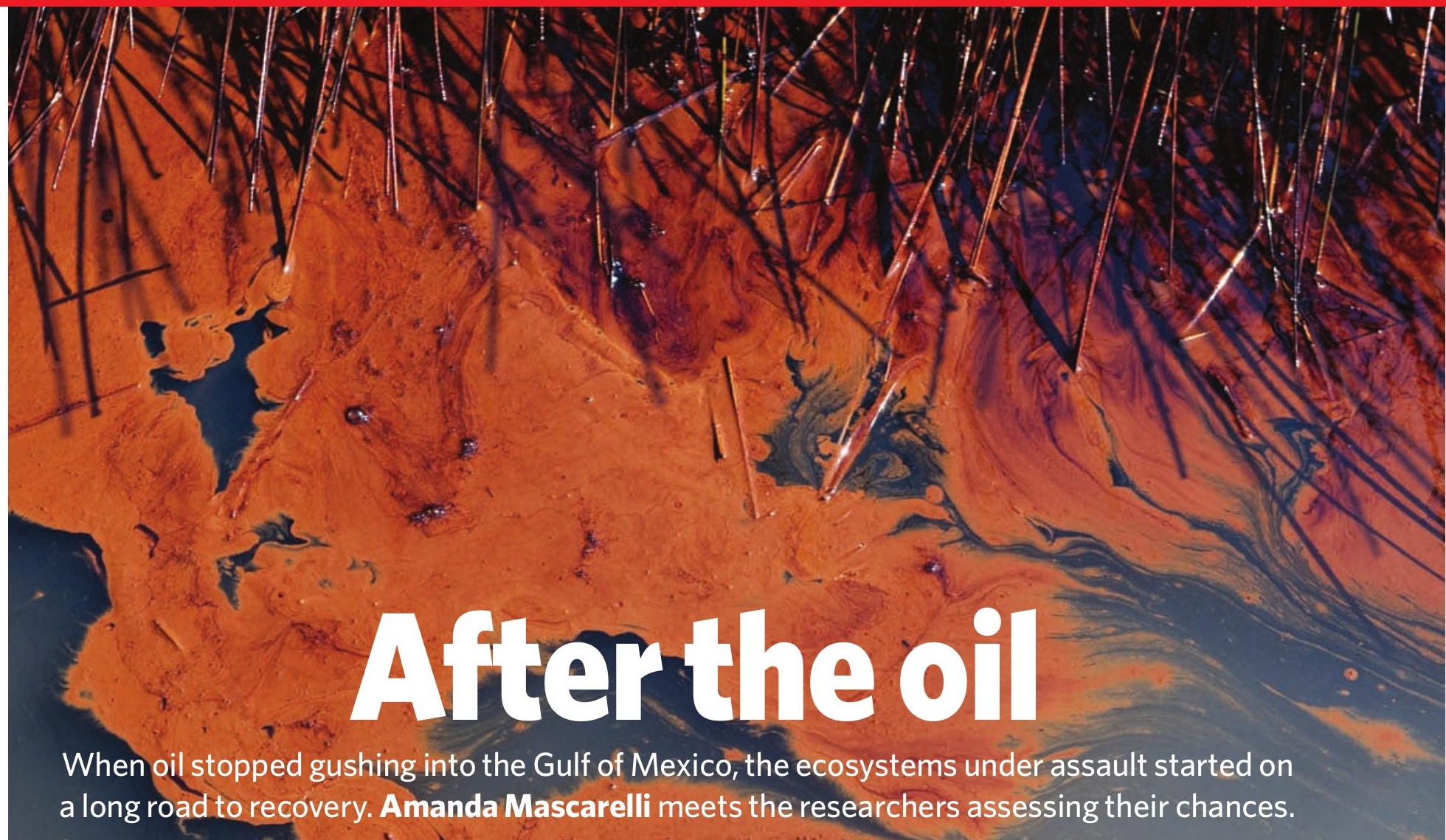

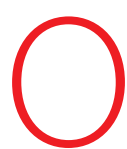
il has been here. It has blasted this tiny barrier island on the southeastern edge of Louisiana, turning the entire rim of wetland vegetation yellow and the surrounding soil black. The flagging marsh grass stems are tinged dull brown, as if they've been dipped in turpentine. As for the animals living in the water below - well, it is hard to know their story.

Kim de Mutsert, a postdoctoral coastal ecologist from Louisiana State University (LSU) in Baton Rouge, is here on a blistering July day to find out. The juvenile crabs, shrimp and fish she is collecting spawned tens to hundreds of kilometres away on the continental shelf in April and May - just when the Deepwater Horizon well was spilling some 10 million litres of oil a day into the Gulf of Mexico. Their eggs and larvae drifted for weeks offshore, bathed in oily water, before the juveniles at last took refuge in the shallow coastal estuaries, where they will mature. De Mutsert is here to discover what harm they have sustained, and what scars will be left on their offspring and on the generations to come.

By the time the Deepwater Horizon well was finally plugged on 15 July, it had spewed some 750 million litres of crude oil into the Gulf and earned the title of the biggest accidental marine oil spill ever. Much of the oil has already vanished from surface waters, and so far the most visible effects have been oiled seabirds, turtles and salt-marsh fringes. Drawing on lessons from past oil spills, many scientists agree that ecosystems have a remarkable capacity to heal. "This is not the end of the Gulf of Mexico," says George Crozier, a marine biologist and head of the Dauphin Island Sea Lab in Alabama.

But history provides an incomplete reference. Aside from its unprecedented size, the spill was the first to release a massive amount of oil 1.5 kilometres down on the sea floor and the first involving widespread use of oil dispersants below water. On top of that, the coastal areas hit hardest — the Louisiana wetlands — are already under acute stress from subsidence, erosion and the damage caused by Hurricane Katrina in 2005. All this means that the long-term consequences for life in the deep water and coastal ecosystems in the Gulf remain unknown. Researchers worry that toxic components in the oil could wipe out generations of some species, but there is no way to predict the effects. And the oil could linger both in the deep ocean and in sediments for months or years, slowly bleeding more pollutants (see 'The unknown fate of oil'). "It's a huge lab experiment, but there are no controls," says Harriet Perry, a fisheries biologist at the University of Southern Mississippi's Gulf Coast Research Laboratory marine-science centre in Ocean Springs, Mississippi. “That's frightening to scientists who always have a control to measure against."

All this means that when the oil stopped, the work for researchers began. "If you look at this as the basis of an experiment, that's $t$-zero," says
William Hawkins, director of the Gulf Coast Research Laboratory. "Now the assessment of damage can start in earnest. We can start to determine the process of recovery."

\section{Probing the wetlands}

At first, scientists worried that the spill would devastate Louisiana's vast wetlands, which cover some 12,000 square kilometres. Around $75-90 \%$ of creatures in the northern Gulf of Mexico spend part or all of their lives in the estuarine waters surrounding these wetlands, which are enriched with nutrients from the Mississippi River. Animals such as oysters and bay anchovies are permanent residents, whereas others such as shrimp move out to sea to spawn and complete their life cycles. Researchers were concerned that important habitat for these creatures could be lost if the oil poisoned wetland root systems - essential for holding sediments in place - and accelerated erosion and subsidence. "Initially, my worst fear was that we would lose the offshore habitat, which is critical, but that we would also lose the nursery grounds, the marshes," says Perry.

But those fears may not be realized. Thanks to favourable winds and currents, aggressive oil skimming and trapping at the surface, and the likelihood that a substantial portion of oil is still drifting in underwater plumes, it seems that the damage so far may be limited. In late August, more than 212 kilometres of Gulf coastline were moderately to heavily oiled, according to an official government estimate. By contrast, a substantial area of some 75 square kilometres of wetlands are lost to erosion and drainage 
every year. "Back of the envelope [calculations] suggest that what we're going to lose from this spill is nowhere close to the background rates of wetland loss," says Alex Kolker, a coastal geologist with the Louisiana Universities Marine Consortium in Chauvin.

The most serious damage may have been done out in the ocean - to organisms that were spawned there and exposed to submerged and dispersed oil as embryos and larvae. To measure such effects, de Mutsert and research technician Elise Roché repeatedly cast a giant trawl net into the water at oiled sites, pulling in juvenile crustaceans and fish such as anchovies, catfish and menhaden. De Mutsert plans to study their size, growth rates and populations and compare them with baseline data that date back to the 1960s, collected by the Louisiana Department of Wildlife and Fisheries.

At the Gulf Coast Research Laboratory, Perry is also assessing the damage by collecting, identifying and measuring larvae and juveniles of various species and recording their numbers. She peers into the microscope and reveals a blue crab larva (Callinectes sapidus), about the size of a pinhead, with droplets of dispersed oil wedged between its skin and outer shell. Perry suspects that the numbers of blue crab larvae, which spawn in open waters $15-150$ kilometres offshore, will drop because of their exposure. She estimates that some $40 \%$ of offshore larval grounds across the north-central Gulf were exposed to oil.

Scientists are keeping a close watch on variables that might affect life in the open ocean, including depleted oxygen levels caused by a feeding frenzy from oil- and gas-eating microbes, and the unknown effects of dispersants, which break the oil into droplets but may keep it suspended in the water ${ }^{1,2}$. Among the greatest concerns is that compounds in oil called polycyclic aromatic hydrocarbons (PAHs) could have long-term sublethal effects on marine organisms that were at the peak of their spawning season when the spill began. PAHs could stunt growth, an effect that could ripple through the ecosystem: smaller organisms are picked off by predators at a young age, leaving less food for larger fish such as red snapper and bluefin tuna. This could have a direct economic impact on Louisiana's fisheries - which account for $75 \%$ of US fisheries productivity in the Gulf of Mexico.

Exposure to PAHs early in an organism's life cycle can also lead to infertility and a host of developmental problems, says Jeffrey Short, an environmental chemist based in Juneau, Alaska, who works with the marine conservation organization Oceana. Short was working for the National Oceanic and Atmospheric Administration in 1989 when the Exxon Valdez

\section{THE UNKNOWN FATE OF OIL}

Among the biggest mysteries of the Deepwater Horizon spill is how long the oil will stick around. The US National Oceanic and Atmospheric Administration announced on 4 August that the "vast majority" of oil had been naturally degraded or cleaned up by skimming, burning and direct recovery; of the remainder, some $16 \%$ had been dispersed into droplets and was degrading quickly, and $26 \%$ hovered below the water surface in tar balls, and in sand and sediments.

Those estimates sparked debate. Oil is a complex organic mixture, and each component has its own degradation rate, determined by a combination of light, temperature, oxidation and microbes. Samantha Joye, a biogeochemist at the University of Georgia in Athens, questions the assumption that the dispersed and dissolved oil will biodegrade quickly. "That's just based on pure fantasy as far as I can tell." And she says that the government's calculations overlook the contribution of hydrocarbons from methane. "It really is astounding to me that they would come out with this oil budget that is $60 \%$ of the equation at best, because the gas is missing," says Joye.

In August, a team of Georgia researchers suggested that nearly $80 \%$ of the oil remains at large. And a study in Science on 19 August $^{7}$, among the first peer-reviewed papers to characterize the spill, suggested that an immense plume stretching more than 35 kilometres had degraded very little between late April and late June, when the measurements were taken.

Following the 1989 Exxon Valdez spill, oil seeped into sediments and lingered in low-oxygen layers where biodegradation is slow. A study published in January ${ }^{8}$ found that oil from the spill persists today in anoxic layers of soil on nearby beaches. Animals such as sea ducks and otters in the affected areas showed boosted levels of liver enzymes, a marker for hydrocarbons, for at least a decade afterwards ${ }^{9,10}$.

How long the oil will persist in Louisiana's wetlands depends on how far it has penetrated into the deep sediments. "The sublethal long-term effect is that you create layers of hydrocarbons in the marine soils that persist for tens of years," says Ian MacDonald, an oceanographer at Florida State University in Tallahassee. Similar layers can still be found in sediments in the mangroves of Veracruz, Mexico, as a result of the Ixtoc I spill in 1979 and at the sites of other oil spills around the world, where subtle signs of damage to wildlife are still found.

A.M.
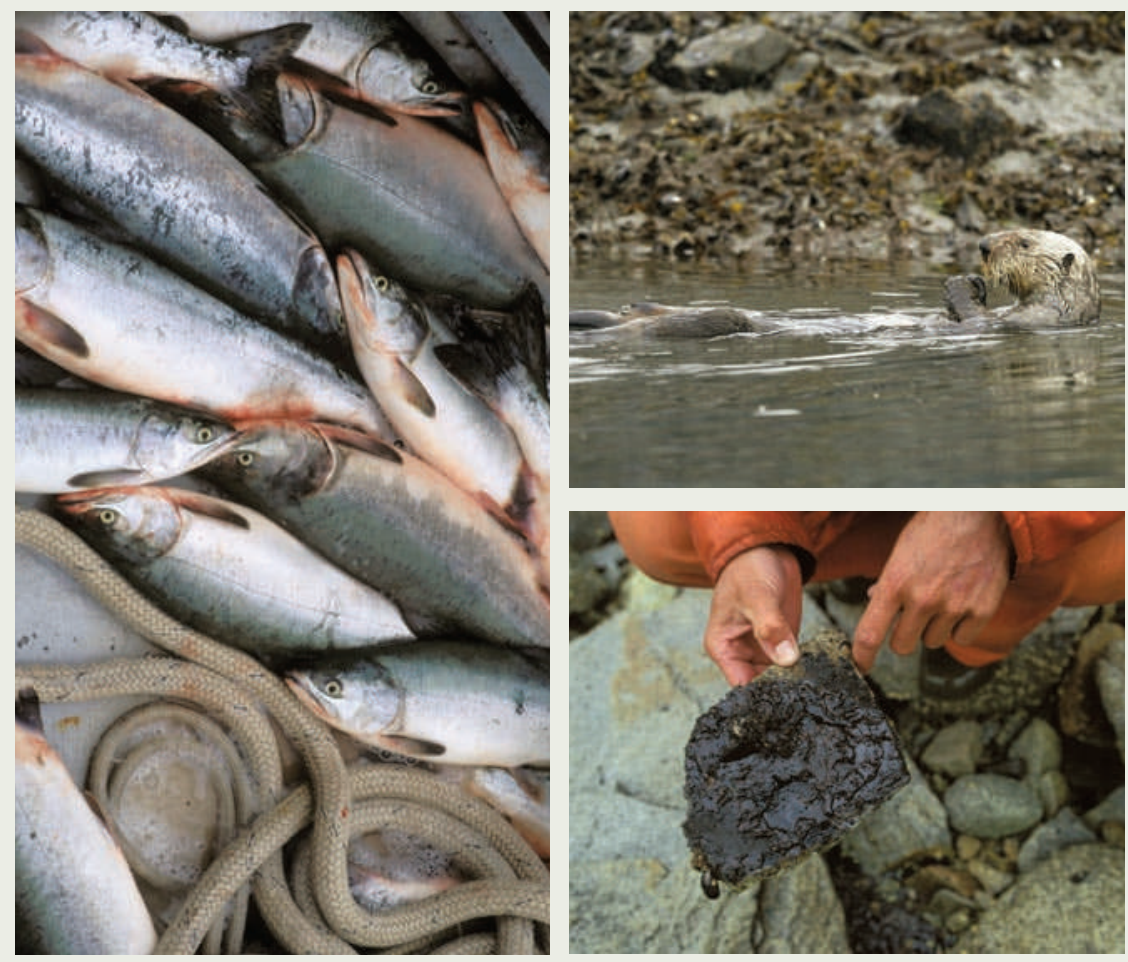

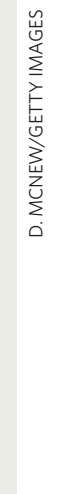

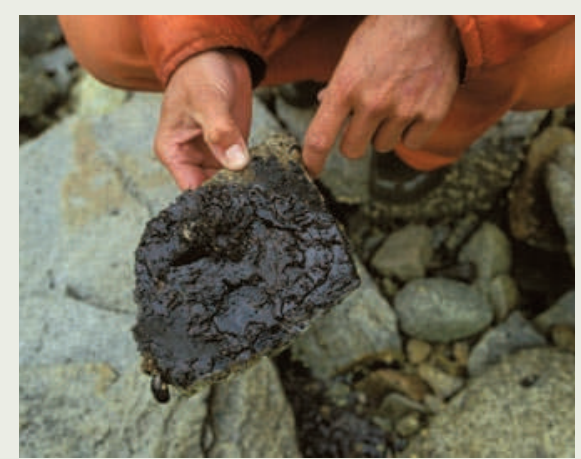

Work on previous spills suggests oil can harm wildlife and linger in sediments for decades. 


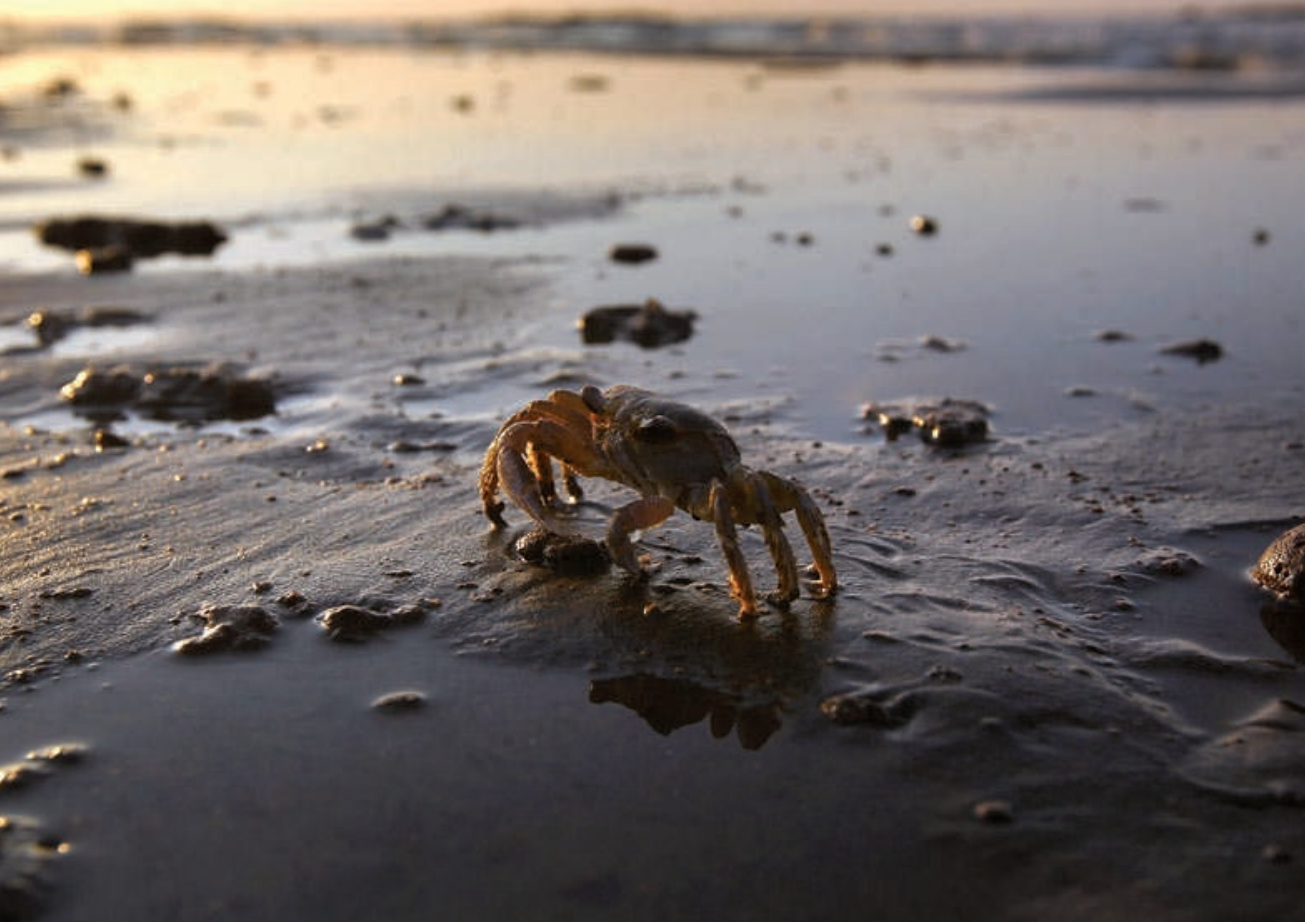

Toxic components of oil could stunt growth and cause mutations in crustaceans and fish in the Gulf.

oil tanker dumped 42 million litres of oil into Prince William Sound in Alaska, and he led much of the research into its effects. Months after the spill, pink salmon eggs that were spawned in intertidal streams where oil was present showed depressed survival compared with those in streams with no oil ${ }^{3}$. And rare mutations that caused salmon to grow an extra fin or an enlarged heart sac, for example, began to turn up in a small fraction of the population, says Short. "It was really difficult to detect because the nature of the damage was that they didn't die at the same time of the same thing," he says. "But it turned out to be an extraordinary impact." Some of these effects subsided after about five years, Short says.

Results from laboratory studies showed that as little as one part per billion of PAHs can damage pink salmon eggs and that similar concentrations affect herring eggs ${ }^{4}$. A study performed under the US government's Natural Resource Damage Assessment programme calculated that oil exposure led to a $52 \%$ loss in larval herring following the spill ${ }^{5}$, although an Exxon-funded study did not support that link ${ }^{6}$.

Short says that it is still too early to tell how PAHs might affect Gulf organisms in either shallow or deep water. The effects will depend on the concentration of oil, how far it has travelled and the exposure time - all unknowns. He remains very concerned about the exposure of animals that inhabit the depths and migrate upwards at night to feed, as well as animals at the sea floor. "It's going to be tough to get those data because it's just so hard to work there."

A throng of reef-dwelling organisms live on the edge of the Gulf of Mexico's continental shelf some 200 kilometres offshore, from corals in the shallower regions to sponges, sea fans and other soft corals, and numerous fish species in the deep. Where the shelf ends and the continental slope drops steeply downwards, waters at 1,500-2,000 metres teem with longlived predatory species such as bluefin tuna, swordfish, marlin and wahoos, which probably all swam through the plume. And on the sea floor, animals that strain food from the water, including tube worms, clams, mussels and barnacles, could also be exposed to oil microdroplets in the water or to residues buried in the sediment.

It could take several years to understand how exposure to the oil in early life will affect fish populations that might not mature and be fished for some time. "I'll

"I don't want everybody
to think we dodged a
bullet and everything
is going to be OK.
There will be ecological
consequences."

he says. Kolker and his colleagues, meanwhile, are using genomic analyses to look at changes in bacterial communities in soils as proxies to understand how the wetlands may be affected by oil. "Bacterial communities respond very quickly to environmental changes," he says.

And starting in August and continuing into September, Samantha Joye, a biogeochemist at the University of Georgia in Athens, and a group of scientists are tracking underwater plumes, retracing the steps of earlier studies to determine how the oil has been travelling in the water column. Her team is also following the path of gas and oil through the food web by tracking how signature carbon isotopes are incorporated into the tissues of organisms.

Joye says the spill is "going to change the way that I do research and what I focus on for the rest of my career". De Mutsert, who is busy writing further grant proposals for oil-related studies, agrees. "We are going to have a lot of oil research scientists," she predicts. "I think this will shape a lot of people's careers."

But that is only if funding keeps on coming. $\mathrm{BP}$ has pledged US $\$ 500$ million for research in the Gulf, although only a small fraction of that has yet been handed out, and many researchers are working under rapid-response grants from the National Science Foundation. But scientists be looking for year class failures - having a hole punched in that year's spawning reproductive success," says Richard Shaw, a fisheries oceanographer at LSU. Fish that live for several decades, such as red snapper and groupers, can recover from such a punch. But animals that live for just one to three years, including shrimp and menhaden, could be knocked flying. "A failed year class for a couple of years in a row could dramatically reduce their populations for a while," says James Cowan, an oceanographer at LSU, in whose lab de Mutsert works. "It could be catastrophic for both the populations and the community of people that relies on them."

\section{A shift in focus}

In late August, Short and his colleagues took a cruise to make some of the first highly sensitive measurements of PAHs at depth. Until now, the instruments used to monitor the water around the spill have not been able to adequately detect PAHs and related long-lasting toxic molecules,
"What I don't want to happen is for everybody to think we dodged a bullet and everything is going to be OK," says Rabalais. "There will be ecological consequences, we just don't really know what they all are at this point." Amanda Mascarelli is a freelance writer based in Denver, Colorado.

1. Mascarelli, A. Nature doi:10.1038/news.2010.378 (2010). 2. Mascarelli, A. Nature doi:10.1038/news.2010.347 (2010).

3. Bue, B. G., Sharr, S. \& Seeb, J. E. Trans. Am. Fish. Soc. 127, 35-43 (1998).

4. Carls, M. G., Rice, S. D. \& Hose, J. E. Environ. Toxicol. Chem. 18, 481-493 (1999).

5. Brown, E. D. et al. Am. Fish Soc. Symp. 18, 448-462 (1996).

6. Pearson, W. H., Moksness, E. \& Skalski, J. R. in Exxon Valdez Oil Spill: Fate and Effects in Alaskan Waters (eds Wells, P. G., Butler, J. N. \& Hughes, J. S.) 626-661 (Am. Soc. Testing and Materials, 1995)

7. Camilli, R. et al. Science doi:10.1126/science.1195223 (2010)

8. Li, H. \& Boufadel, M. C. Nature Geosci. 3, 96-99 (2010).

9. Esler, D. et al. Mar. Ecol. Prog. Ser. 241, 271-286 (2002)

10. Bodkin, J. L. et al. Mar. Ecol. Prog. Ser. 241, 237-253 (2002).

For more on the spill, see News, page 16, and online at www.nature.com/oilspill. 